\title{
PENGARUH KESADARAN WAJIB PAJAK, SANKSI PERPAJAKAN DAN PENERAPAN SISTEM E-FILING TERHADAP KEPATUHAN WAJIB PAJAK ORANG PRIBADI (STUDI KASUS KANTOR PELAYANAN PAJAK PRATAMA PONDOK GEDE
}

\author{
Indah Permadani $^{1}$ \\ Program Studi Akuntasi Fakultas Ekonomi \\ Universitas Krisnadwipayana \\ Indah.permadani9@gmail.com \\ Dewi Rejeki ${ }^{2}$ \\ Program Studi Akuntasi Fakultas Ekonomi \\ Universitas Krisnadwipayana \\ dewi.and71@gmail.com
}

\begin{abstract}
The objective of this research is to find out the effect of Taxpayer Awereness, Tax Sanctions, and aplication of e-Filing system for individual Taxpayer compliance in KPP Pratama Pondok Gede. The research method is descriptive and quantitative research methods. The type of data is primary data.The results of this research had effect of taxpayer awareness, tax sanctions and aplication of e-Filing system for individual taxpayer compliance in KPP Pratama Pondok Gede. The conclusion of this research shows that taxpayer awereness has a partial effect on the compliance of individual taxpayer, tax sanctions don't have a partial effect on the compliance of individual tax payer, aplication of e-filing system has a partial effect on the compliance of individual tax payer, taxpayer awareness, tax sactions, and application of e-filing system has simultaneously affects on the compliance of individual taxpayer.
\end{abstract}

Keyword : Taxpayer Awereness, Tax Sanctions, e-Filing System, Taxpayer Compliance

\section{PENDAHULUAN}

Pajak adalah kontribusi wajib rakyat kepada negara yang terutang, baik sebagai orang pribadi atau badan usaha yang sifatnya memaksa berdasarkan Undang-Undang dengan tidak mendapat imbalan secara langsung dan digunakan untuk keperluan negara bagi sebesar-besarnya kemakmuran rakyat. Pembayaran pajak merupakan peran serta Wajib Pajak untuk ikut serta secara langsung dan bersama-sama untuk melaksanakan pembiayaan negara dan pembangunan nasional.

Pajak memiliki kontribusi yang cukup tinggi dalam penerimaan negara non-migas. Pada Mei 2018 realisasi penerimaan dari sektor fiskal mencapai lebih dari 75 persen dari total penerimaan dalam APBN. Berbagai kebijakan dalam bentuk ekstentifikasi dan intentifikasi telah dibuat oleh pemerintah dalam rangka untuk meningkatkan penerimaan negara dari sektor fiskal. Kebijakan tersebut tentunya berdampak pada masyarakat dan pihak-pihak yang berperan sebagai pembayar, pemotong dan pemungut pajak.

Penerimaan pajak pemerintah selalu meleset dari target Anggaran Pendapatan dan Belanja Negara (APBN). Contohnya pada realisasi pajak tahun 2017-2018, realisasi setoran pajak tahun 2017 hanya tercapai 89,4 persen atau sebesar Rp 1 147,5 Triliun dari target APBN 2017 sebesar Rp 1 283,6 Triliun dan tahun lalu realisasi setoran pajak tahun 2018 baru mencapai 92 persen atau sebesar Rp 1 315,9 Triliun dari target APBN 2018 sebesar Rp1. 424 Triliun. Artinya masih kekurangan target penerimaan pajak sebesar Rp 108,1 Triliun. Ada beberapa hal yang menyebabkan penerimaan pajak belum mencapai target meskipun ekonomi Indonesia tumbuh dikisaran 5 persen. Salah satunya adalah masyarakat belum patuh membayar pajak, karena alasan pengisian Surat Pemberitahuan (SPT) Tahunan Pajak Penghasilan ( $\mathrm{PPh})$ dinilai sulit. Orang akan membayar pajak apabila mengisi SPT jauh lebih mudah. 
Dalam penerapan Self Assessment System, Kesadaran Wajib Pajak adalah faktor penting dalam merealisasikan tercapainya target dari penerimaan pajak. Kesadaran wajib pajak adalah suatu keadaan dimana wajib pajak mengetahui, memahami, dan melakukan ketentuan perpajakan dengan benar dan sukarela. Semakin tinggi tingkat kesadaran wajib pajak, maka penerimaan pajak akan semakin meningkat. Sedangkan semakin menurunnya kesadaran wajib pajak, maka penerimaan pajak akan semakin menurun. Oleh karena itu menumbuhkan kesadaran wajib pajak seharusnya sudah menjadi agenda utama Direktorat Jenderal Pajak (DJP). Kesadaran wajib pajak akan terus meningkat seiring dengan berjalannya waktu. Jika Wajib Pajak sendiri sudah memiliki rasa percaya atas fiskus atau administrasi pajak yang semakin membaik.

Kepatuhan Wajib Pajak meliputi kepatuhan mencatat atau membukukan transaksi usaha, kepatuhan melakukan pembayaran pajak kegiatan usaha sesuai peraturan yang berlaku, serta kepatuhan yang paling mudah diamati adalah kepatuhan melaporkan kegiatan usaha. Hal ini karena seluruh Wajib Pajak mempunyai kewajiban menyampaikan laporan kegiatan usaha atau penghasilan yang dimilikinya setiap bulan dan atau setiap tahunnya dalam bentuk menyampaikan Surat Pemberitahuan (SPT). Menurut Gunadi (2013:94), kepatuhan wajib pajak adalah kesediaan untuk memenuhi kewajiban perpajakannya sesuai dengan aturan yang berlaku tanpa perlu diadakan pemeriksaan investigasi seksama, peringatan ataupun ancaman dan penerapan sanksi baik hukum maupun administrasi.

Tingkat kepatuhan wajib pajak di Kantor Pelayanan Pajak (KPP) Pratama Pondok Gede sendiri menunjukkan kondisi yang masih relatif rendah yang diakibatkan oleh Wajib Pajak Orang Pribadi yang sudah mendaftarkan dirinya, namun kemudian tidak melaporkan SPT Tahunannya. Maka membuat KPP Pratama Pondok Gede terus berusaha melakukan hal-hal yang dapat meningkatkan Kepatuhan Wajib Pajak. Hal ini dapat dilihat dari data jumlah Wajib Pajak Orang Pribadi yang belum sesuai dengan jumlah Wajib Pajak yang melaporkan SPT nya.
Tabel 1. Tingkat Kepatuhan Wajib Pajak Tahun 2016-2018

\begin{tabular}{|c|c|c|c|c|c|}
\hline $\begin{array}{l}\text { Tah } \\
\text { un }\end{array}$ & $\begin{array}{l}\text { Juml } \\
\text { ah } \\
\text { Waji } \\
\text { b } \\
\text { Pajak }\end{array}$ & $\begin{array}{l}\text { Total } \\
\text { WPO } \\
\text { P }\end{array}$ & $\begin{array}{l}\text { Total } \\
\text { WP } \\
\text { OP } \\
\text { Lapo } \\
\text { r } \\
\text { SPT }\end{array}$ & $\begin{array}{l}\text { Siste } \\
\text { m } E- \\
\text { filin } \\
g\end{array}$ & $\begin{array}{l}\text { Tingkat } \\
\text { Kepatu } \\
\text { han }(\%)\end{array}$ \\
\hline 2016 & $\begin{array}{l}212.3 \\
06\end{array}$ & $\begin{array}{l}191.7 \\
74\end{array}$ & $\begin{array}{l}54.99 \\
0\end{array}$ & $\begin{array}{l}47.9 \\
32 \\
\end{array}$ & 63 \\
\hline 2017 & $\begin{array}{l}227.2 \\
45\end{array}$ & $\begin{array}{l}204.9 \\
84\end{array}$ & $\begin{array}{l}55.94 \\
7\end{array}$ & $\begin{array}{l}50.6 \\
33 \\
\end{array}$ & 54 \\
\hline 2018 & $\begin{array}{l}244.2 \\
07 \\
\end{array}$ & $\begin{array}{l}219.7 \\
45 \\
\end{array}$ & $\begin{array}{l}54.11 \\
1 \\
\end{array}$ & $\begin{array}{l}53.7 \\
04 \\
\end{array}$ & 46 \\
\hline
\end{tabular}

Tabel 2. Target dan Realisasi Penerimaan Pajak

\begin{tabular}{|l|l|l|}
\hline $\begin{array}{l}\text { Tahu } \\
\text { n }\end{array}$ & Target & Realisasi \\
\hline 2016 & 1.113 .541 .582 .99 & 1.072 .240 .694 .67 \\
& 9 & 9 \\
\hline 2017 & $\begin{array}{l}1.215 .877 .343 .00 \\
\\
0\end{array}$ & $\begin{array}{l}1.190 .167 .758 .56 \\
2\end{array}$ \\
\hline 2018 & $\begin{array}{l}1.433 .844 .845 .00 \\
0\end{array}$ & $\begin{array}{l}1.369 .532 .841 .57 \\
2\end{array}$ \\
& 0 & . \\
\hline
\end{tabular}

Dapat dilihat dari data yang ada diatas dimana pencapaian tingkat kepatuhan wajib pajak di Kantor Pelayanan Pajak (KPP) Pratama Pondok Gede menunjukan presentase yang menurun di setiap tahunnya. Hal ini memberikan gambaran bahwa Wajib Pajak masih memiliki kesadaran yang relatif rendah yang akan berdampak pada rendahnya Tingkat Kepatuhan Wajib Pajak di KPP Pratama Pondok Gede.

Permasalahan kepatuhan wajib pajak di Kantor Pelayanan Pajak (KPP) Pratama Pondok Gede dipengaruhi oleh beberapa faktor. Salah satu faktor tersebut adalah masih rendahnya Kesadaran Wajib Pajak untuk melaporkan SPT Pajak di setiap bulan dan setiap tahun. Karena kasus yang sering terjadi ketika Wajib Pajak yang telah membayar Pajak, namun mereka tidak melaporkan SPT . Sehingga mereka dikategorikan sebagai Wajib Pajak yang tidak patuh.

Kesadaran Wajib Pajak di KPP Pondok Gede yang masih rendah dalam hal melaporkan SPT Pajaknya membuat Kantor Pelayanan Pajak Pratama Pondok Gede 
DOI: http://dx.doi.org/10.35137/jabk.v6i3.323 melakukan berbagai cara baik dari Sosialisasi ataupun Edukasi. Sosialisasi yang dilakukan oleh KPP Pratama Pondok Gede berupa Sosialisasi didalam Kantor maupun diluar Kantor. Sosialisasi didalam tersebut, telah diadakan Kelas Pajak untuk memberikan Edukasi kepada Wajib Pajak yang baru terdaftar melalui kegiatan Tripel One (1 Minggu, 1 Bulan, 1 Tahun). Sedangkan untuk Sosialisasi diluar yaitu, kegiatan Edukasi Pajak yang dilakukan setiap tanggal 4 sampai 6 Maret setiap tahun, dengan mendirikan stan di mall guna membantu para Wajib Pajak terutama Wajib Pajak Orang Pribadi dalam melaporkan SPT Tahunan.

Cara lain yang dilakukan untuk meningkatkan Kepatuhan Wajib Pajak yaitu dengan menerapan Sanksi Perpajakan bagi Wajib Pajak yang tidak patuh dalam membayar serta melaporkan pajaknya. Salah satu sanksi yaitu sanksi bagi WP Orang Pribadi yang telat melapor akan dikenakan denda sebesar Rp 100.000,00 dan sanksi bagi WP Badan yang telat melapor dengan denda sebesar Rp 1.000.000,00. Hal ini dilakukan guna membuat para Wajib Pajak jera dan tidak telat maupun menunggak lagi dan sadar akan kewajiban dalam melapor dan membayar pajak.

Selain itu modernisasi sistem juga merupakan salah satu cara untuk meningkatkan kepatuhan wajib pajak. Modernisasi yang dilakukan yaitu dengan merubahnya SPT manual menggunakan SPT elektronik atau lebih dikenal dengan Sistem $E$ filing. Menurut Sigit Hutomo (2018:40), pengertian E-Filing adalah cara penyampaian SPT atau penyampaian Pemberitahuan Perpanjangan SPT Tahunan secara elektronik yang dilakukan secara online dan real time melalui Penyedia Jasa Aplikasi.

E-filing merupakan salah satu sistem perpajakan yang telah di modernisasi yang bertujuan untuk memudahkan Wajib Pajak dalam melakukan pelaporan pajaknya Dengan menggunakan Sistem E-filing diharapkan Wajib Pajak yang melapor lebih banyak lagi. Karena dengan menggunakan fasilitas ini Wajib Pajak telah dimudahkan untuk melaporkan pajaknya melalui Online tanpa harus repot-repot pergi ke Kantor Pajak. Batas waktu penyampaian $e$-Filing ini selama 24 jam sehari dan 7 hari seminggu dengan standar Waktu Indonesia Bagian Barat dan apabila disampaikan pada hari libur, dianggap disampaikan tepat waktu.

Berdasarkan uraian dan judul terkait dengan kesadaran, sanksi administrasi dan $e$ filling serta kepatuhan wajib pajak diatas, maka tujuan daripanda penelitian ini adalah :

1. Untuk mengetahui pengaruh Kesadaran Wajib Pajak terhadap Kepatuhan Wajib Pajak Orang Pribadi

2. Untuk mengetahui pengaruh Sanksi Perpajakan terhadap Kepatuhan Wajib Pajak Orang Pribadi

3. Untuk mengetahui pengaruh Penerapan Sistem E-filing terhadap Kepatuhan Wajib Pajak Orang Pribadi

4. Untuk mengetahui pengaruh Kesadaran Wajib Pajak, Sanksi Perpajakan dan Penerapan Sistem E-filing terhadap Kepatuhan Wajib Pajak Orang Pribadi

\section{METODOLOGI PENELITIAN}

Objek penelitian ini, yaitu para Wajib Pajak Orang Pribadi (WPOP) yang berada di KPP Pratama Pondok Gede yang berada di wilayah kecamatan Bekasi Selatan, kota Bekasi. Para Wajib Pajak Orang Pribadi tersebut akan menjawab pertanyaan dalam bentuk kuisioner yang telah disusun oleh peneliti. Penelitian ini dilakukan mulai bulan Desember 2018 sampai dengan selesai.

Dalam penelitian ini variabel yang digunakan adalah kesadaran wajib pajak, $\left(\mathrm{X}_{1}\right)$, sanksi perpajakan, $\left(\mathrm{X}_{2}\right)$, penerapan sistem $e$ filing (X3) dan kepatuhan wajib pajak (Y).

Variabel penelitian ini diukur oleh instrumen pengukur dalam bentuk angket atau kuesioner berskala likert. Skala Likert digunakan untuk mengukur suatu sikap, pendapat dan persepsi seseorang atau sekelompok orang tentang suatu fenomena sosial.

Populasi yang diteliti adalah wajib pajak orang pribadi (WPOP) di KPP Pratama Pondok Gede kota Bekasi sebanyak 227.336 wajib pajak. Untuk menghitung penentuan jumlah sampel dari populasi tertentu yang dikembangkan, maka digunakan rumus Slovin dengan tingkat kesalahan sebesar $10 \%$. Hasil perhitungan sampelnya adalah sebagai berikut: 
DOI: http://dx.doi.org/10.35137/jabk.v6i3.323

$$
\begin{aligned}
n=\frac{227.336}{227.336\left(0,1^{2}\right)+1} \\
=99,956 \\
=100
\end{aligned}
$$

Data yang diperoleh melalui survey langsung pada Objek Penelitian dengan metode pengumpulan data pada penelitian ini menggunakan metode wawancara dan kuesioner. Wawancara dilakukan untuk memperoleh dengan para wajib pajak yang sedang melapor di KPP Pratama Pondok Gede untuk mendapatkan informasi yang diinginkan. Sedangkan kuesinoer dilakukan melalui daftar pertanyaan yang disiapkan untuk tiap responden yang sedang melakukan pelaporan pajak di KPP Pratama Pondok Gede kota Bekasi.

Metode analisis data yang digunakan dalam penelitian ini adalah metode analisis kuantitatif, yaitu metode yang menggunakan prosedur-prosedur statistik dengan alat bantu pengolahan data berupa program IBM SPSS 25. Analisis dimulai dengan mengambarkan berbagai karakteritik data dari suatu sampel yang biasa dikenal dengan statistik deskriptif. Selanjutnya data akan diuji kualitasnya dengan uji validitas dan reliabilitas. Uji asumsi klasik dilakukan dengan menggunakan uji normalitas, uji multikolonieritas dan uji heteroskedastisitas. Kemudian dilakukan dengan melakukan analisis regresi linier berganda dan terakhir dilakukan pengujian hipotesis berupa uji-T (parsial) dan uji-F (Simultan).

\section{HASIL DAN PEMBAHASAN}

Kantor Pelayanan Pajak Pratama Pondok Gede merupakan Instansi Vertikal Direktorat Jendral Pajak yang merupakan pecahan dari Kantor Pelayanan Pajak Pratama Bekasi Selatan. KPP Pratama Pondok Gede mempunyai tugas melaksanakan penyuluhan, pelayanan dan pengawasan Wajib Pajak di bidang Pajak Penghasilan, Pajak Pertambahan Nilai, Pajak Penjualan atas Barang Mewah, dan Pajak Tidak Langsung lainnya dalam wilayah wewenang KPP Pratama Pondok Gede berdasarkan peraturan perundangundangan.

Sebelum berubah nama menjadi Kantor Pelayanan Pajak (KPP) Pratama
Pondok Gede, dulunya kantor ini merupakan bagian dari Kantor Pelayanan Pajak (KPP) Pratama Bekasi Selatan. Pada tanggal 5 Oktober 2015, Kantor pelayanan pajak (KPP) pratama Pondok Gede dibentuk berdasarkan Keputusan Menteri Keuangan nomor 206.2/PMK.01/2014 tanggal 17 Oktober 2014 tentang Organisasi dan Tata Kerja Instansi Vertikal Direktorat Jenderal Pajak, sebagai Kantor Pelayanan Pajak yang menerapkan Sistem Administrasi Perpajakan Modern yang mulai boroperasi pada tanggal 5 Oktober 2015 dengan beralamatkan di Gedung Mgold Tower lantai UG, 21 dan 22 di Jalan KH. Noer Alie, Kelurahan Pekayon Jaya, Kecamatan Bekasi Selatan, Bekasi. Adapun wilayah kerja KPP Pratama Pondok Gede meliputi 4 (empat) kecamatan, yaitu Pondok Gede, Jatiasih, Pondok Melati, dan Jatisampurna.

\section{Statistik Deskripsi}

Penyajian statistik deskriptif bertujuan untuk menggambarkan karakter sampel dalam penelitian serta memberikan deskripsi variabel yang digunakan dalam penelitian. Dalam penelitian ini variabel yang digunakan adalah Kesadaran Wajib Pajak, Sanksi Perpajakan dan Penerapan Sistem E-filing serta Kepatuhan Wajib Pajak. Analisis penelitian berdasarkan pada hasil jawaban responden atas 39 pernytaan. Berikut merupakan statistik deskriptif yang disajikan dalam tabel 3 :

Tabel 3. Statistik Deskriptif Variabel

\begin{tabular}{|l|l|l|l|l|l|}
\hline & $\mathrm{N}$ & $\begin{array}{l}\text { Minimu } \\
\mathrm{m}\end{array}$ & $\begin{array}{l}\text { Maximu } \\
\mathrm{m}\end{array}$ & Mean & $\begin{array}{l}\text { Std. } \\
\text { Deviati } \\
\text { on }\end{array}$ \\
\hline KWP & $\begin{array}{l}10 \\
0\end{array}$ & 18 & 30 & 27,5 & 2,492 \\
\hline $\mathrm{SP}$ & $\begin{array}{l}10 \\
0\end{array}$ & 12 & 25 & 18,76 & 2,965 \\
\hline $\mathrm{PE}$ & $\begin{array}{l}10 \\
0\end{array}$ & 80 & 115 & 104,6 & 8,081 \\
\hline $\mathrm{KP}$ & 10 & 16 & 25 & 22,87 & 1,968 \\
\hline $\begin{array}{l}\text { Valid } \\
\mathrm{N} \\
\text { (listwis }\end{array}$ & $\begin{array}{l}0 \\
\mathrm{e})\end{array}$ & & & & \\
\hline
\end{tabular}

\section{Analisis Hasil Penelitian Uji Kualitas Data}

1. Uji Validitas 
DOI: http://dx.doi.org/10.35137/jabk.v6i3.323

Dengan menggunakan uji dua sisi (two-tailed) dengan taraf signifikansi 5\% maka nilai $\mathrm{r}$ tabel dalam penelitian ini adalah 0,1966. Item pernyataan dinyatakan valid jika $r$ hitung $>r$ tabel.

Berdasarkan hasil Uji Validitas Variabel Kesadaran Wajib Pajak (X1), Sanksi Perpajakan (X2), Sistem E-Filling (X3) dan Kepatuhan Wajib Pajak (Y) maka dapat disimpulkan bahwa seluruh item pernyataan pada keempat variabel dinyatakan valid, dikarenakan memiliki nilai $r$ hitung $>r$ tabel.

2. Uji Reliabilitas

Dengan menggunakan uji statistic Cronbach Alpha (a) > 0,7 menunjukkan bahwa hasil uji realiabilitas untuk empat variabel penelitian yang digunakan dalam penelitian ini adalah sebagai berikut :

Tabel 4.Hasil Uji Reliabilitas Instrumen Variabel Penelitian

\begin{tabular}{|l|l|l|l|}
\hline Variabel & $\begin{array}{l}\text { Jumlah butir } \\
\text { pernyataan } \\
\text { alpha }\end{array}$ & $\begin{array}{l}\text { Cronbach } \\
\text { Kesimpulan }\end{array}$ \\
\hline $\begin{array}{l}\text { Kesadaran } \\
\text { Wajib Pajak }\end{array}$ & 6 butir & 0,792 & Reliable \\
\hline $\begin{array}{l}\text { Penerapan } \\
\text { Sistem } \quad \text { - } \\
\text { Filing }\end{array}$ & 23 butir & 0,921 & Reliable \\
\hline $\begin{array}{l}\text { Sanksi } \\
\text { Perpajakan }\end{array}$ & 5 butir & 0,444 & Reliable \\
\hline $\begin{array}{l}\text { Kepatuhan } \\
\text { Wajib Pajak }\end{array}$ & 5 butir & 0,768 & Reliable \\
\hline \multicolumn{2}{|l|}{ Sumber: Data diolah oleh Peneliti 2019} & \\
\hline
\end{tabular}

Berdasarkan Tabel 4, hasil Uji Reliabilitas, maka dapat disimpulkan bahwa variabel Kesadaran Wajib Pajak (X1), Sanksi Perpajakan (X2) dan Penerapan Sistem Efiling (X3) serta Kepatuhan Wajib Pajak (Y) mempunyai alpha $(\alpha)$ diatas 0,7 yang berarti semua variabel dalam penelitian ini dapat diandalkan atau diterima untuk pengujian hipotesis.

Uji Asumsi Klasik

1. Uji Normalitas

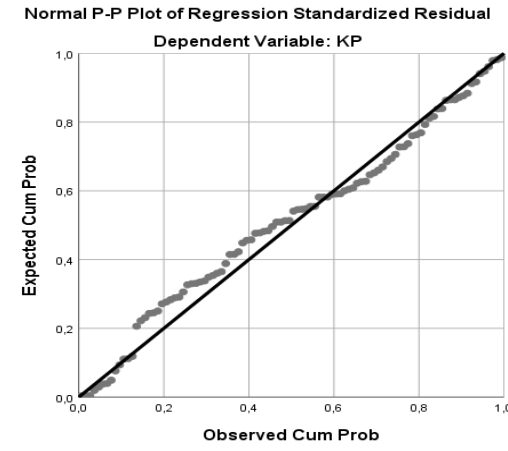

Sumber: Data diolah oleh Peneliti 2019

Gambar 1. Hasil Uji Normalitas

Pada gambar di atas menunjukkan adanya persebaran (titik) pada sumbu diagonal yang mendekati garis diagonal. Berdasarkan pedoman uji normalitas menyatakan bahwa jika persebaran titik mengikuti atau mendekati garis normal maka suatu penelitian dapat dikatakan normal. Untuk meyakinkan bahwa penelitian ini menunjukkan adanya normalitas, maka dilakukan pengujian dengan menggunakan pengujian histogram.

2. Uji Mulitikolinearitas

Tabel 5.Hasil Uji Multikolinearitas

\begin{tabular}{|c|c|c|c|}
\hline \multicolumn{4}{|c|}{ Coefficients $^{\mathrm{a}}$} \\
\hline \multicolumn{2}{|c|}{ Model } & \multicolumn{2}{|c|}{ Collinearity Statistics } \\
\hline & & Tolerance & VIF \\
\hline \multirow[t]{4}{*}{1} & (Constant) & & \\
\hline & $\begin{array}{l}\text { KESADARAN } \\
\text { WAJIB } \\
\text { PAJAK }(X 1)\end{array}$ & 551 & 1,814 \\
\hline & $\begin{array}{l}\text { SANKSI } \\
\text { PERPAJAKAN( } \\
\text { X2) }\end{array}$ & ,943 & 1,060 \\
\hline & \begin{tabular}{l}
\multicolumn{2}{l}{ PENERAPAN } \\
SISTEM \\
FILING(X3)
\end{tabular} & ,528 & 1,895 \\
\hline
\end{tabular}

Multikolinearitas diatas, hasil perhitungan nilai Tolerance menunjukkan tidak ada variabel yang memiliki nilai Tolerance kurang dari 0,10 yang berarti tidak ada korelasi antar variabel independen yang lainnya lebih dari 95\%. Hasil perhitungan nilai Variance Inflation Factor (VIF) juga menunjukkan hal yang sama tidak ada satu variabel independen yang memiliki nilai VIF lebih dari 10. Jadi dapat disimpulkan bahwa 
DOI: http://dx.doi.org/10.35137/jabk.v6i3.323 tidak ada multikolinearitas antar variabel independen dalam model regresi.

3. Uji Heteroskedastisitas

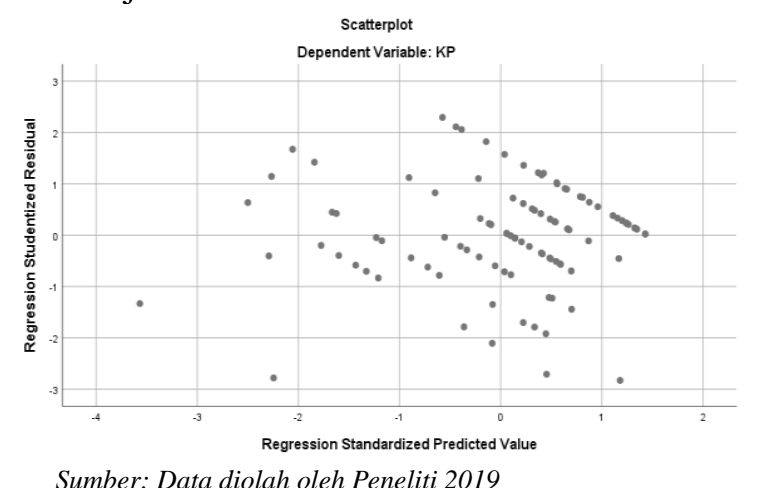

Gambar 2. Hasil Uji Heteroskedastisitas

Pada gambar di atas menunjukkan tidak terjadi pola tertentu yang teratur seperti gelombang, melebar, dan lainnya. Sesuai dengan pedoman uji heteroskedastisitas, maka dalam penelitian ini tidak terjadi heteroskedastisitas atau disebut homokedastisitas. Hal ini membuktikan dengan grafik plot di atas yang tidak membentuk pola tertentu yang teratur sehungga penelitian ini layak dilakukan pengujian lebih lanjut.

\section{Analisis Regresi Linier Berganda}

Dengan menggunakan metode analisis linier regresi berganda, didapat hasil pengolahan data analisis regresi sebagai berikut.

Tabel 6. Analisis Regresi Linier Berganda

\begin{tabular}{|c|c|c|c|c|c|}
\hline \multicolumn{6}{|l|}{ Coffiticients $^{a}$} \\
\hline \multirow[t]{2}{*}{ Model } & \multicolumn{2}{|c|}{ Instandardiced Coefficentsts } & Standardizad Coefficients & T & Sig \\
\hline & $B$ & Std. Eroror & Beth & & \\
\hline (Constatit) & 3,003 & 1.854 & & 1.600 & .100 \\
\hline KESADARANWAIBPPAAK XII & 215 & .07 & 213 & 2987 & . O.t \\
\hline SANKSIPERPAAKAN(XE) &., 030 & 046 & .16 6 & .608 & 512 \\
\hline 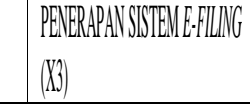 & 1,18 & , DB & .266 & 5,638 & , OOO \\
\hline
\end{tabular}

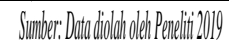

Berdasarkan hasil analisis regresi di atas, maka dapat diperoleh suatu persamaan garis regresi sebagai berikut :

$$
\begin{gathered}
Y=3,003+0,215 X 1+0,030 X 2 \\
+0,128 X 3+e
\end{gathered}
$$

Keterangan :

$$
\begin{array}{ll}
\mathrm{Y} & =\text { Kepatuhan Wajib Pajak } \\
\mathrm{a} & =\text { Konstanta } \\
\mathrm{X}_{1} & =\text { Kesadaran Wajib Pajak } \\
\mathrm{X}_{2} & =\text { Sanksi Perpajakan } \\
\mathrm{X}_{3} & =\text { Penerapan Sitem } \text { e-Filing } \\
\mathrm{e} & =\text { Error }
\end{array}
$$

Berdasarkan tabel diatas, untuk uji regresi berganda dapat dijelaskan sebagai berikut :

a. Konstanta 3,003 artinya jika semua variabel independen tetap (konstan), maka kepatuhan wajib pajak nilainya 3,003 .

b. Koefisien regresi variabel Kesadaran Wajib Pajak (X1) sebesar 0,215, artinya jika variabel kesadaran wajib pajak mengalami peningkatan satu satuan, maka pemahaman Kepatuhan Wajib Pajak akan mengalami peningkatan sebesar 0,215. Hal ini menunjukkan bahwa semakin tinggi kesadaran wajib pajak maka kepatuhan wajib pajak akan semakin baik.

c. Koefisien regresi variabel Sanksi Perpajakan (X2) sebesar 0,030, artinya jika variabel sanksi perpajakan mengalami peningkatan satu satuan, maka kepatuhan wajib pajak akan mengalami peningkatan sebesar 0,030. Sehingga dapat dinyatakan bahwa sanksi perpajakan secara parsial tidak berpengaruh signifikan terhadap kepatuhan WPOP.

d. Koefisien regresi variabel Penerapan Sistem E-filing (X3) sebesar 0,128, artinya jika variabel penerapan sistem $e$ filing mengalami peningkatan satu satuan, maka kepatuhan wajib pajak akan mengalami peningkatan sebesar 0,128. Hal ini menunjukkan bahwa para Wajib Pajak setuju atas indikator penerapan sistem $e$-filing untuk mempermudah wajib pajak dalam membayar dan melaporkan pajaknya. Mereka juga bersedia mengikuti kegiatan sosialisasi dan pembelajaran mengenai tata cara penggunaan sistem $e$-filing.

\section{Koefisien Determinasi $\left(R^{2}\right)$}

Koefisien determinasi pada intinya mengukur seberapa jauh kemampuan model dapat menjelaskan variasi variabel dependen. Pada pengujian hipotesis pertama koefisien determinasi dilihat dari besarnya nilai 
DOI: http://dx.doi.org/10.35137/jabk.v6i3.323

(Adjusted R2) untuk mengetahui seberapa jauh variabel independen yaitu kesadaran wajib pajak, sanksi perpajakan, dan penerapan sistem e-filing terhadap kepatuhan WPOP. Hasil dari uji koefisien determinasi dapat dilihat pada tabel di bawah ini:

Tabel 7. Hasil Uji Koefisien Determinasi $\left(\mathrm{R}^{2}\right)$

\begin{tabular}{|l|l|l|l|l|}
\hline \multicolumn{2}{|c|}{ Model Summary } \\
\hline Model & $\mathrm{R}$ & $\begin{array}{l}\mathrm{R} \\
\text { Square }\end{array}$ & $\begin{array}{l}\text { Adjusted } \\
\text { R Square }\end{array}$ & $\begin{array}{l}\text { Std. Error } \\
\text { of the } \\
\text { Estimate }\end{array}$ \\
\hline 1 &, $747^{\text {a }}$ &, 558 &, 544 & 1,328 \\
\hline
\end{tabular}

Berdasarkan tabel di atas dapat terlihat hasil adjusted R2 dari variabel-variabel independen dalam penelitian ini adalah sebesar 0,558. Hal ini berarti bahwa 55,8\% dari kepatuhan WPOP dipengaruhi oleh variabelvariabel independen dalam penelitian ini yakni kesadaran wajib pajak, sanksi perpajakan dan kepatuhan WPOP. Sedangkan 44,2\% lainnya dijelaskan oleh variabel-variabel lain yang tidak termasuk di dalam model regresi penelitian ini.

Kekuatan Variabel Kesadaran Wajib Pajak, Sanksi Perpajakan, serta Penerapan Sistem E-filing secara bersama-sama, dalam menjelaskan Kepatuhan Wajib Pajak Orang Pribadi sebesar 54,4\% $\left(\mathrm{R}^{2}=0,544\right)$. Sedangkan untuk 45,6\% lainnya dipengaruhi oleh kekuatan variabel lain. Salah satunya adalah Variabel Pelayanan Fiskus. Dengan memberikan pelayanan perpajakan yang lebih baik, nyaman, ramah, mudah, efisien dan tidak berbelit-belit, akan membuat Wajib Pajak tidak beranggapan bahwa membayar pajak itu merupakan hal yang berbelit-belit yang harus dihindari. Sehingga Pelayanan Perpajakan ini dimaksudkan untuk meningkatkan pemasukan pajak ke kas negara.

\section{Pembahasan}

Berdasarkan hasil penelitian yang dilakukan dengan melibatkan 100 orang responden WPOP di Kantor Pelayanan Pajak Pratama Pondok Gede dengan membandingkan penelitian terdahulu adalah sebagai berikut :
1. Pengaruh Kesadaran Wajib Pajak Terhadap Kepatuhan Wajib Pajak Orang Pribadi

Tabel 8. Hasil Uji Parsial (Uji-t)

\begin{tabular}{|c|c|c|c|c|c|c|}
\hline \multicolumn{7}{|c|}{ Coefficients $^{\mathbf{a}}$} \\
\hline \multirow{2}{*}{\multicolumn{2}{|c|}{ Model }} & \multicolumn{2}{|c|}{$\begin{array}{l}\text { Unstandard } \\
\text { ized } \\
\text { Coefficient } \\
\text { S }\end{array}$} & $\begin{array}{l}\text { Standard } \\
\text { ized } \\
\text { Coeffici } \\
\text { ents }\end{array}$ & \multirow[t]{2}{*}{$\mathrm{T}$} & \multirow[t]{2}{*}{$\begin{array}{l}\mathrm{Si} \\
\mathrm{g} .\end{array}$} \\
\hline & & B & Std & Beta & & \\
\hline \multirow[t]{3}{*}{1} & (Constant & $\begin{array}{l}9,3 \\
35\end{array}$ & $\begin{array}{l}1,70 \\
1\end{array}$ & & $\begin{array}{l}5,4 \\
87\end{array}$ & $\begin{array}{l}, 00 \\
0\end{array}$ \\
\hline & KESADA & ,4 & 06 & ,628 & 7,9 & .00 \\
\hline & $\begin{array}{l}\text { RAN } \\
\text { WAJIB } \\
\text { PAJAK } \\
\text { (X1) }\end{array}$ & 96 & 2 & & 88 & 0 \\
\hline
\end{tabular}

Berdasarkan hasil Uji-t pada tabel di atas, maka dapat disimpulkan dengan derajat kepercayaan 5\%, variabel kesadaran wajib pajak $\left(\mathrm{X}_{1}\right)$ berpengaruh signifikan secara statistik terhadap kepatuhan wajib pajak orang pribadi (WPOP) (Y). Hal ini dapat dilihat dari thitung > t-tabel $(7,988>1,985)$. Sementara untuk uji signifikansi konstanta dan variabel independen, dari tabel di atas diperolah nilai signifikansi sebesar $0,000<0,05(\alpha)$. Dengan demikian, maka $\mathrm{H}_{1}$ yang menyatakan bahwa kesadaran wajib pajak $\left(\mathrm{X}_{1}\right)$ berpengaruh terhadap kepatuhan WPOP (Y) diterima ( $\mathbf{H}_{1}$ diterima). Hal ini berarti terdapat pengaruh kesadaran wajib pajak terhadap kepatuhan wajib pajak orang pribadi.

2. Pengaruh Sanksi Perpajakan Terhadap Kepatuhan Wajib Pajak Orang Pribadi

Tabel 9. Hasil Uji Parsial (Uji-t)

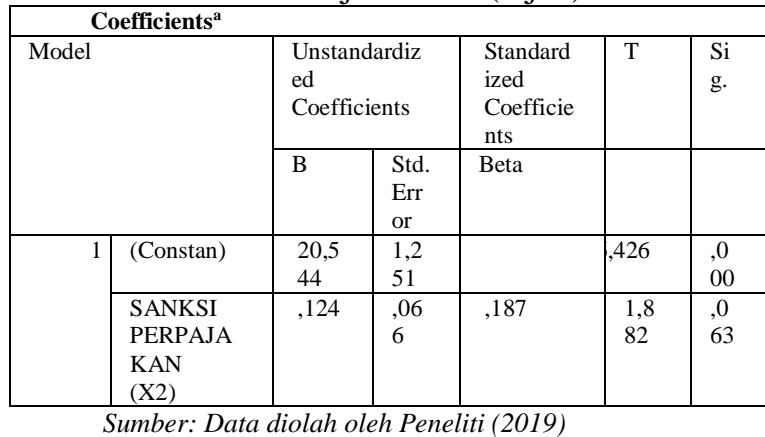

Berdasarkan hasil Uji-t pada tabel di atas, maka dapat disimpulkan dengan derajat kepercayaan 5\%, variabel Sanksi perpajakan $\left(\mathrm{X}_{2}\right)$ tidak berpengaruh signifikan secara statistik terhadap kepatuhan WPOP. Hal ini dapat dilihat 
DOI: http://dx.doi.org/10.35137/jabk.v6i3.323 dari thitung < ttabel $(1,882<1,985)$. Sementara untuk uji signifikansi konstanta dan variabel independen, dari tabel di atas diperolah nilai signifikansi sebesar $0,063>0,05 \quad(\alpha)$. Dengan demikian, maka $\mathrm{H}_{2}$ yang menyatakan bahwa Sanksi Perpajakan $\left(\mathrm{X}_{2}\right)$ berpengaruh terhadap Kepatuhan WPOP (Y) ditolak ( $\mathbf{H}_{2}$ ditolak). Hal ini berarti tidak terdapat pengaruh sanksi perpajakan terhadap kepatuhan WPOP.

3. Pengaruh Penerapan Sistem e-Filing Terhadap Kepatuhan Wajib Pajak Orang Pribadi

Tabel 10. Hasil Uji Parsial (Uji-t)

\begin{tabular}{|c|c|c|c|c|c|c|}
\hline \multicolumn{7}{|c|}{ Coefficients $^{\mathrm{a}}$} \\
\hline \multirow{2}{*}{\multicolumn{2}{|c|}{ Model }} & \multicolumn{2}{|c|}{$\begin{array}{l}\text { Unstandard } \\
\text { ized } \\
\text { Coefficient } \\
\text { s }\end{array}$} & $\begin{array}{l}\text { Standar } \\
\text { dized } \\
\text { Coeffici } \\
\text { ents }\end{array}$ & \multirow[t]{2}{*}{$\mathrm{T}$} & \multirow[t]{2}{*}{$\begin{array}{l}\mathrm{Si} \\
\mathrm{g} .\end{array}$} \\
\hline & & B & $\begin{array}{l}\text { St } \\
\text { d. } \\
\text { Err } \\
\text { or }\end{array}$ & Beta & & \\
\hline 1 & (Constant & $\begin{array}{l}4,5 \\
59\end{array}$ & $\begin{array}{l}1,7 \\
95\end{array}$ & & $\begin{array}{l}2,54 \\
0\end{array}$ & $\begin{array}{l}, 01 \\
3\end{array}$ \\
\hline & $\begin{array}{l}\text { PENERA } \\
\text { PAN } \\
\text { SISTEM } \\
\text { E- } \\
\text { FILING } \\
(\mathrm{X} 3)\end{array}$ & $\begin{array}{l}, 17 \\
5\end{array}$ & $\begin{array}{l}, 01 \\
7\end{array}$ & ,719 & $\begin{array}{l}10,2 \\
31\end{array}$ & $\begin{array}{l}, 0 \\
00\end{array}$ \\
\hline
\end{tabular}

Berdasarkan hasil Uji-t pada tabel di atas, maka dapat disimpulkan dengan derajat kepercayaan 5\%, variabel Penerapan Sistem E-filing $\left(\mathrm{X}_{3}\right)$ berpengaruh signifikan secara statistik terhadap Kepatuhan WPOP (Y). Hal ini dapat dilihat dari thitung >ttabel $(10,231$ $>1,985)$. Sementara untuk uji signifikansi konstanta dan variabel independen, dari tabel di atas diperolah nilai signifikansi sebesar $0,005<0,05 \quad(\alpha)$. Dengan demikian, maka $\mathrm{H}_{3}$ yang menyatakan bahwa sosialisasi dan pelatihan $\left(\mathrm{X}_{3}\right)$ berpengaruh terhadap pemahaman UMKM atas SAK EMKM (Y) diterima $\left(\mathbf{H}_{3}\right.$ diterima). Hal ini berarti terdapat pengaruh penerapan sistem e-filing atas Kepatuhan WPOP.

4. Pengaruh Kesadaran Wajib Pajak, Sanksi Perpajakan dan Penerapan Sistem E-filing Terhadap Kepatuhan Wajib Pajak Orang Pribadi.
Tabel 11. Hasil Uji Simultan (Uji F)

\begin{tabular}{|c|c|c|c|c|c|c|}
\hline \multicolumn{7}{|c|}{ ANOVA $^{a}$} \\
\hline \multicolumn{2}{|c|}{ Model } & Sum of & D & Mean & & Sig. \\
\hline \multirow[t]{3}{*}{1} & $\begin{array}{l}\text { Regressi } \\
\text { on }\end{array}$ & $\begin{array}{l}213,99 \\
9\end{array}$ & 3 & $\begin{array}{l}71,33 \\
3\end{array}$ &, 44 & $\begin{array}{l}, 00 \\
0^{\mathrm{b}}\end{array}$ \\
\hline & Residual & $\begin{array}{l}169,31 \\
1\end{array}$ & & 1,764 & & \\
\hline & Total & $\begin{array}{l}383,3 \\
10\end{array}$ & & & & \\
\hline
\end{tabular}

Sumber: Data yang Diolah oleh Peneliti (2019)

Hasil uji $F$ pada tabel tersebut menghasilkan angka Fhitung > Ftabel, yaitu 40,446> 2,698 dan signifikansi sebesar 0,000. Dengan demikian $\mathrm{H}_{4}$ diterima, yang berarti variabel independen yaitu kesadaran wajib pajak, sanksi perpajakan, dan penerapan sistem e-filing mempengaruhi variabel dependen yaitu kepatuhan WPOP secara simultan. Hasil tersebut menunjukkan bahwa Kesadaran Wajib Pajak responden beserta besar Sanksi Perpajakan mereka dan dilengkapi dengan Penerapan Sistem $E$ filing secara bersama-sama akan mempengaruhi pemahaman Kepatuhan Wajib Pajak Orang Pribadi di KPP Pratama Pondok Gede.

\section{KESIMPULAN}

Berdasarkan hasil penelitian yang telah dilakukan, maka dapat ditarik beberapa kesimpulan antara lain Kesadaran wajib pajak berpengaruh secara parsial terhadap kepatuhan wajib pajak orang pribadi. Dengan demikian hal ini menunjukkan bahwa semakin tinggi kesadaran wajib pajak mengenai pentingnya membayar dan melaporkan pajak, maka akan semakin tinggi pula kepatuhan wajib pajak dalam membayar dan melaporkan pajaknya di KPP Pratama Pondok Gede.

Sanksi Perpajakan tidak berpengaruh secara parsial terhadap kepatuhan wajib pajak orang pribadi. Hal ini menunjukan apabila semakin menurunnnya sanksi perpajakan maka akan semakin menurun pula kepatuhan wajib pajak dalam membayar serta melaporkan pajaknya di KPP Pratama Pondok Gede.

$$
\text { Penerapan Sistem E-filing }
$$
berpengaruh secara parsial terhadap kepatuhan wajib pajak orang pribadi. Hal ini menunjukkan bahwa semakin ditingkatkannya sistem baru yang memudahkan para wajib 
DOI: http://dx.doi.org/10.35137/jabk.v6i3.323

pajak maka akan semakin banyak wajib pajak yang akan membayar dan melaporkan pajaknya, sehingga kepatuhan wajib pajak pun ikut meningkat.

Kesadaran Wajib Pajak, Sanksi Perpajakan, dan Penerapan sistem e-filing berpengaruh secara simultan terhadap Kepatuhan wajib pajak orang pribadi. Hal ini menunjukkan bahwa tinggi atau rendahnya kepatuhan wajib pajak orang pribadi, sangat dipengaruhi oleh kesadaran wajib pajak, sanksi perpajakan dan penerapan sistem $e$ filing yang dilakukan oleh pegawai perpajakan.

Dalam penelitian ini ditemukan bahwa variabel Penerapan Sistem E-filing memiliki pengaruh paling dominan yang mempengaruhi diantara variabel lainnya terhadap kepatuhan wajib pajak, dapat dilihat berdasarkan nilai standard coefficien beta sebesar 0,128.

\section{DAFTAR PUSTAKA}

Budiarto, A. 2016. Pedoman Praktis Membayar Pajak. Yogyakarta : Genesis Learning.

Butarbutar Russel. 2017. Hukum Pajak Indonesia dan Internasional. Bekasi : Gramata Publishing.
Gunadi. 2016. Panduan Komprehensif Ketentuan Umum Perpajakan (KUP). Jakarta : MUC Consulting

Group .

Halim A. 2016. Perpajakan Edisi 2. Jakarta : Salemba Empat.

Imam Ghozali. 2018. Aplikasi Analisis Multivariate Dengan Program IBM SPSS 25. Semarang : UNDIP

Mardiasmo. 2016. Perpajakan. Jakarta : Andi.

Nasution. 2006. Perpajakan. Jakarta: Bumi Aksara

Priantara D. 2016. Perpajakan Indonesia Edisi 3. Jakarta : Mitra Wacana Media.

Prasetyo A. 2016. Konsep dan Analisis Risiko Pajak. Jakarta : Elex Media Komputindo.

Resmi S. 2016. Perpajakan: Teori dan Kasus. Jakarta : Salemba Empat.

Sari D. 2016. Konsep Dasar Perpajakan. Bandung : PT Refika Aditama.

Sigit H. 2018. Terampil Pajak Penghasilan. Yogyakarta : C.V Andi Offset.

Sugiyono. 2013. Metode Penelitian Manajemen. Bandung : C.V Alfabeta 
ISSN : 2406-7415

e-ISSN : 2655-9919

JURNAL AKUNTANSI DAN BISNIS KRISNADWIPAYANA Vol. 6 No. 3 (September - Desember) 2019

DOI: http://dx.doi.org/10.35137/jabk.v6i3.323 